IZA DP No. 7890

Is Soccer Good for You? The Motivational Impact of Big Sporting Events on the Unemployed

Philipp Doerrenberg

Sebastian Siegloch

January 2014 


\title{
Is Soccer Good for You? The Motivational Impact of Big Sporting Events on the Unemployed
}

\author{
Philipp Doerrenberg \\ Centre for European Economic Research (ZEW), \\ CGS, University of Cologne and IZA \\ Sebastian Siegloch \\ IZA and University of Cologne
}

Discussion Paper No. 7890

January 2014

IZA

P.O. Box 7240

53072 Bonn

Germany

Phone: +49-228-3894-0

Fax: +49-228-3894-180

E-mail: iza@iza.org

\begin{abstract}
Any opinions expressed here are those of the author(s) and not those of IZA. Research published in this series may include views on policy, but the institute itself takes no institutional policy positions. The IZA research network is committed to the IZA Guiding Principles of Research Integrity.

The Institute for the Study of Labor (IZA) in Bonn is a local and virtual international research center and a place of communication between science, politics and business. IZA is an independent nonprofit organization supported by Deutsche Post Foundation. The center is associated with the University of Bonn and offers a stimulating research environment through its international network, workshops and conferences, data service, project support, research visits and doctoral program. IZA engages in (i) original and internationally competitive research in all fields of labor economics, (ii) development of policy concepts, and (iii) dissemination of research results and concepts to the interested public.
\end{abstract}

IZA Discussion Papers often represent preliminary work and are circulated to encourage discussion. Citation of such a paper should account for its provisional character. A revised version may be available directly from the author. 
IZA Discussion Paper No. 7890

January 2014

\section{ABSTRACT}

\section{Is Soccer Good for You? The Motivational Impact of Big Sporting Events on the Unemployed}

We examine the effect of salient international soccer tournaments on the motivation of unemployed individuals to search for employment using the German Socio Economic Panel 1984-2010. Exploiting the random scheduling of survey interviews, we find significant effects on motivational variables such as the intention to work or the reservation wage. Furthermore, the sporting events increase perceived health as well as worries about the general economic situation.

JEL Classification: D8, J2, J6

Keywords: $\quad$ sporting events, soccer, unemployment, well-being

Corresponding author:

Sebastian Siegloch

IZA

P.O. Box 7240

53072 Bonn

Germany

E-mail: siegloch@iza.org 


\section{Introduction}

Professional international soccer tournaments such as the FIFA World Cup or the UEFA Euro Cup attract enormous attention in many countries. Germany is one country in which these soccer tournaments are especially salient: media coverage is very high during the tournaments and a substantial share of the population is presumably affected and excited by the sporting event. ${ }^{1}$ This excitement is likely to translate into emotional cues (Kavetsos and Szymanski, 2010; Card and Dahl, 2011), which in turn may have an effect on economic variables. Various studies confirm that soccer events have economic effects. For example, Dohmen et al. (2006) employ telephone surveys in Germany before and after the 2006 World Cup to find that the "seemingly irrelevant" tournament had an effect on economic perceptions and expectations. Edmans et al. (2007) report significant effects of soccer games on stock market returns and Lozano (2011) finds that workers in the US adjust their labor supply during FIFA World Cup tournaments. ${ }^{2}$

We use the German Socio Economic Panel (SOEP), 1984 - 2010, to examine the effect of the Euro Cup and the World Cup on the motivation of unemployed individuals to search for employment and on measures of well-being and economic expectations. Our identification strategy rests on the fact that there are no individual characteristics that determine when a participant is interviewed. In other words, we exploit that survey interviews are randomly scheduled within the interviewing period. After conditioning on potentially confounding seasonal effects including a full set of month fixed effects, our approach allows the comparison of individuals who are interviewed before a tournament (control group) to those who are interviewed afterwards (treated group) within one tournament year. Our estimates represent a causal relationship as long as there is no selection into the treated group driven by unobserved factors.

Our results indicate that the unemployed are affected by the soccer tournaments along many dimensions. We show that respondents who are interviewed after a tournament have an increased motivation to work but, at the same time, request higher reservation wages. Furthermore, the sporting events increase the perceived health status as well as worries about the general economic situation. We also find effects on the subjective well-being of men. Placebo effects, for which we estimate the same regression models but for non-tournament years, support our identification strategy.

\footnotetext{
${ }^{1}$ For example, when Germany and Spain played in the semi-final of the 2010 World Cup, approximately 31 million Germans watched the game on television (FIFA, 2010).

${ }^{2}$ Several other studies find effects of soccer and sporting events on stock markets (Scholtens and Peenstra, 2009; Kaplanski and Levy, 2010; Ehrmann and Jansen, 2012), labor market outcomes (Thoursie, 2004), college grades (Lindo et al., 2012), and violence (Gantz et al., 2006; Rees and Schnepel, 2009; Card and Dahl, 2011).
} 


\section{Empirical Strategy}

Data and Sample Our main data source is the representative and annually conducted German Socio Economic Panel (SOEP, 2011). We rely on all available waves that were carried out during a year in which either a FIFA World Cup or UEFA Euro Cup was held, ${ }^{3}$ leaving us with 14 waves between 1984 and 2010. We are solely interested in unemployed individuals and exclude all participants from our sample who indicated to be employed. Summary statistics are presented in Table A.1 in the Appendix.

Main Variables The main explanatory variable, labeled treatment, is a dummy that is "one" if a participant is interviewed after a tournament in a given year and "zero" if before. We exclude all respondents who are interviewed during a tournament. Data on the exact dates of the tournaments were collected from the websites of the FIFA and UEFA.

We study the effects on two sets of dependent variables, to which we refer as motivational variables and well-being variables. The motivational variables comprise variables that are likely to be relevant for the decision of an unemployed person to start or continue looking for a job. Variable Intention indicates when a respondent plans on working again. It combines two questions from the survey: first, whether a respondent generally plans to work again; and second, if yes, when he intends to start looking for employment. The variable is measured on a 5-point scale (Coding: 0: "never", 1: "in more than 5 years", 2: "in 2 to 5 years", 3: "within the next year", 4: "asap"). We further examine what type of job someone is interested in (dummy variable type of work indicating "full time"), the perceived difficulty to find a job (variable difficulty with 1: "virtually impossible" to 3: "easy") and the logged number of desired working hours. Finally, reservation indicates the logged and deflated "monthly salary at which someone would take a job". ${ }^{4}$

The well-being variables include satisfaction and health variables. Life satisfy measures life satisfaction in general on an eleven-point scale (10: "highest satisfaction") and health status indicates the perceived health status on a five-point scale (1: "bad" to 5: "very good"). We also examine the effect on pers. worries and gen. worries. The former depicts "worries about personal finances" and the latter measures "worries about economic development in general" (Coding for both variables: 1: "very concerned" to 3 : "no worries at all").

\footnotetext{
${ }^{3}$ Both tournaments take place every four years. The first World Cup in our sample was held in 1986, the first Euro Cup in the data was in 1984.

${ }^{4}$ We top- and bottom-coded this variable by excluding the lower and upper one percentiles due to a few unreliable responses.
} 
Regression Model To identify the effect of soccer tournaments on our dependent variables, we estimate the following regression model:

$$
Y_{i, s, m, t}=\alpha+\beta \times T_{i, s, m, t}+\delta \times U R_{s, m, t}+W_{s, m, t}+H_{s, m, t}+\lambda_{m}+\mu_{t}+\epsilon_{i, s, m, t},
$$

where subscripts indicate a person $i$ who is surveyed in federal state $s$ during the $m$-th month of year $t$. $Y$ is one of the dependent variables and $T$ is the treatment dummy. Our coefficient of interest is $\beta$ and $\epsilon$ is an error term.

Identification Equation 1 is estimated utilizing OLS where standard errors are clustered by individuals. ${ }^{5}$ Our identification strategy exploits the fact that interviewing dates are random in the sense that there are no individual characteristics which determine at which point during the survey interviewing period a person is surveyed. ${ }^{6}$ However, the soccer tournaments are held during the early summer months (between May and July) making it likely that the results of simply regressing $Y$ on $T$ are confounded by seasonal effects. For example, work motivation or life satisfaction may be higher during late summer, i.e., after a tournament, than in the months before. We take several steps to combat this possible threat to identification. First, we include a full set of month fixed effects, $\lambda$, in order to control for any effects which are specific to certain months. This accounts for any systematic differences in the levels of, for example, motivation between months within one year. Second, we condition on vector $W$, which contains local (federal state-level) weather variables at the interview day. Third, we control for the monthly unemployment rate $U R$ in state $s$. Fourth, we include variables measuring the days until the beginning of the summer high school holidays and the days since the end of the holidays, as well as a dummy taking "1" during holidays (all in vector $H$ ). ${ }^{7}$ We only exploit within year variation by including a full set of year fixed effects $\mu_{t}$ which control for year specific characteristics and time trends.

Summing up our identification strategy, we argue that random scheduling of interview dates, along with conditioning on a set of seasonal variables, allows the comparison of survey participants who are interviewed after a tournament to those who are interviewed

\footnotetext{
${ }^{5}$ Robustness checks, in which we re-estimate all regressions with ordered probit models that are more capable of accounting for the categorical nature of some dependent variables, leave the results qualitatively unaffected.

${ }^{6}$ This is confirmed by scientists administrating the SOEP. The interviewing period lasts from January to December, yet $99 \%$ of all interviews are conducted by September of each year.

${ }^{7}$ The rationale is that people might be in a better mood during or shortly after/before school holidays. In Germany, the 16 federal states set the dates for the school holidays implying that the holidays start at different points of times in different federal states. The weather variables are second-order polynomials of temperature, rainfall and sunshine hours and come from the National Meteorological Service of Germany (Deutscher Wetterdienst, $D W D$ ). Unemployment data are retrieved from the Federal Employment Agency (Bundesagentur für Arbeit: "Amtlichen Nachrichten der Bundesagentur für Arbeit") and holiday dates are obtained from statistics of the federal states.
} 
before. ${ }^{8}$ Identification is supported by additionally conducting placebo tests where we estimate the same regression model but for non-tournament years. The treatment variable in these placebo tests is based on the date of the tournament in the respective subsequent tournament year. For example, suppose in year $t$ the tournament took place between May 20th and June 10th. For the placebo tests, we use the non-tournament year $t-1$ and treat somebody as treated if she is interviewed after June 10th of year $t-1$.

\section{Results}

In this section, we present our results separately for our two sets of dependent variables: motivational (section 3.1) and well-being (3.2) variables.

\subsection{Motivational Variables}

Table 1 displays the coefficients of interest for the motivational variables. Models I to V present several specifications for each of the dependent variables: intention when to work again (I), perceived difficulty to find a job (II), reservation wage (III), desired working hours (IV) and the willingness to work full-time (V).

Panel A is our baseline estimate following equation 1. The soccer tournament has a positive and statistically significant effect on all motivational variables except the number of desired working hours. Treated survey respondents have a higher motivation to start searching for a job again (Model I) and to work full-time rather than part-time (V). They also seem to be more confident in the sense that the perceived difficulty of finding a new job decreases (II). An increased level of confidence might also explain that their reservation wage increases (III). ${ }^{9}$ Note that the results are economically significant as well. For example, being interviewed after a tournament increases the intention to work full-time by 24.9 percentage points.

In Panel B, we include several covariates to the regressions (skill level, gender, age, marital status). All coefficients remain positive and significant except for the "perceived difficulty of finding a job" (II). Panels C and D examine heterogeneous effects with respect to gender and age. In line with expectations, we find that women seem to be less affected by the soccer tournaments. The reservation wage remains positive but is significantly smaller than for men (III). Interestingly, model $\mathrm{V}$ depicts that the tournament effect for treated women on the willingness to work full time is smaller and even negative. Intuitively, we find that the intention to work again decreases in age. We further estimate

\footnotetext{
${ }^{8}$ Schüller (2012) examines the effect of the $9 / 11$ terrorist attacks using a comparable approach.

${ }^{9} \mathrm{We}$ also estimated the effect on a dummy variable that indicates if a respondent could accept a suitable job immediately. The results are positive and significant in all specifications and therefore in line with our reported variable intention.
} 
significant (negative) heterogeneous effects with respect to age for the perceived difficulty to find a job. We also tested for heterogeneous effects with respect to the skill level of the unemployed and found that the effects of the tournaments exist for unemployed of all skill levels (results not reported). Note that this tests also rules out the possibility that our estimates are only driven by high-skilled unemployed who might have postponed their search effort to after the tournament.

In Panel E, where we only use West German data, the results are very similar to the baseline specification. The placebo tests for the non-tournament years, displayed in Panel F, yield very small coefficients that are not distinguishable from zero in a statistical sense. This suggests that we are able to account for potential seasonal confounders and, along with the positive coefficients for the treatment years, that we are able to identify the effect of soccer tournaments.

Table 1: Effects on motivational variables

\begin{tabular}{|c|c|c|c|c|c|}
\hline $\begin{array}{l}\text { Model: } \\
\text { Panel }\end{array}$ & $\begin{array}{c}\mathrm{I} \\
\text { intention }\end{array}$ & $\begin{array}{c}\text { II } \\
\text { diffic find job }\end{array}$ & $\begin{array}{c}\text { III } \\
\text { reservation }\end{array}$ & $\begin{array}{c}\text { IV } \\
\text { hours }\end{array}$ & $\begin{array}{c}\mathrm{V} \\
\text { work full-time }\end{array}$ \\
\hline \multicolumn{6}{|l|}{ A. Baseline } \\
\hline$\overline{\text { treat }}$ & $\begin{array}{c}0.819^{* * *} \\
(0.157)\end{array}$ & $\begin{array}{c}0.149^{* *} \\
(0.071)\end{array}$ & $\begin{array}{c}0.508^{* * *} \\
(0.067)\end{array}$ & $\begin{array}{r}0.147 \\
(0.2)\end{array}$ & $\begin{array}{c}0.249^{* * *} \\
(0.052)\end{array}$ \\
\hline \multicolumn{6}{|c|}{ B. Including Controls } \\
\hline treat & $\begin{array}{c}0.380^{* *} \\
(0.168)\end{array}$ & $\begin{array}{c}0.018 \\
(0.067)\end{array}$ & $\begin{array}{c}0.340^{* * *} \\
(0.063)\end{array}$ & $\begin{array}{l}0.221 \\
(0.17)\end{array}$ & $\begin{array}{l}0.091^{*} \\
(0.051)\end{array}$ \\
\hline \multicolumn{6}{|c|}{ C. Gender Interaction } \\
\hline treat & $\begin{array}{c}0.819^{* * *} \\
(0.157)\end{array}$ & $\begin{array}{l}0.149^{* *} \\
(0.071)\end{array}$ & $\begin{array}{c}0.507^{* * *} \\
(0.067)\end{array}$ & $\begin{array}{l}0.413^{*} \\
(0.227)\end{array}$ & $\begin{array}{c}0.252^{* * *} \\
(0.051)\end{array}$ \\
\hline treat $*$ female & $\begin{array}{l}-0.116 \\
(0.103)\end{array}$ & $\begin{array}{c}0.059 \\
(0.044)\end{array}$ & $\begin{array}{c}-0.335^{* * *} \\
(0.038)\end{array}$ & $\begin{array}{c}-0.258^{* * *} \\
(0.087)\end{array}$ & $\begin{array}{c}-0.319^{* * *} \\
(0.031)\end{array}$ \\
\hline \multicolumn{6}{|l|}{ D. Age Interaction } \\
\hline treat & $\begin{array}{c}0.838^{* * *} \\
(0.157)\end{array}$ & $\begin{array}{c}0.160^{* *} \\
(0.071)\end{array}$ & $\begin{array}{c}0.507^{* * *} \\
(0.067)\end{array}$ & $\begin{array}{c}0.162 \\
(0.198)\end{array}$ & $\begin{array}{c}0.250^{* * *} \\
(0.051)\end{array}$ \\
\hline treat $*$ mid-age & $\begin{array}{l}-0.074 \\
(0.087)\end{array}$ & $\begin{array}{c}-0.206^{* * *} \\
(0.048)\end{array}$ & $\begin{array}{c}0.025 \\
(0.047)\end{array}$ & $\begin{array}{c}-0.011 \\
(0.1)\end{array}$ & $\begin{array}{c}-0.078^{* *} \\
(0.037)\end{array}$ \\
\hline treat $*$ old & $\begin{array}{c}-1.296^{* * *} \\
(0.128)\end{array}$ & $\begin{array}{c}-0.571^{* * *} \\
(0.049)\end{array}$ & $\begin{array}{c}0.087 \\
(0.062)\end{array}$ & $\begin{array}{l}-0.141 \\
(0.127)\end{array}$ & $\begin{array}{l}-0.068 \\
(0.045)\end{array}$ \\
\hline \multicolumn{6}{|c|}{ E. West Germany only } \\
\hline treat & $\begin{array}{c}0.831^{* * *} \\
(0.181)\end{array}$ & $\begin{array}{c}0.188^{* *} \\
(0.08)\end{array}$ & $\begin{array}{c}0.474^{* * *} \\
(0.075)\end{array}$ & $\begin{array}{l}-0.058 \\
(0.228)\end{array}$ & $\begin{array}{c}0.237^{* * *} \\
(0.061)\end{array}$ \\
\hline \multicolumn{6}{|l|}{ F. Placebo Test } \\
\hline$\overline{\text { placebo treat }}$ & $\begin{array}{c}0.034 \\
(0.154) \\
\end{array}$ & $\begin{array}{l}-0.013 \\
(0.061) \\
\end{array}$ & $\begin{array}{c}0.047 \\
(0.066) \\
\end{array}$ & $\begin{array}{c}0.093 \\
(0.169) \\
\end{array}$ & $\begin{array}{c}0.053 \\
(0.053) \\
\end{array}$ \\
\hline Obs. (baseline) & 11326 & 10304 & 5610 & 1139 & 9234 \\
\hline Obs. (west only) & 6594 & 5768 & 2864 & 721 & 5179 \\
\hline Obs. (placebo) & 10092 & 9526 & 4608 & 1051 & 8335 \\
\hline $\begin{array}{l}\text { OLS Regressions. } \\
\text { Significance levels } \\
\text { table displays the } \\
\text { dent variable is di } \\
\text { All coefficients are } \\
\text { seasonal effects in } \\
\text { graphic variables. } \\
\text { treatment dummy } \\
\text { subsequent year. }\end{array}$ & $\begin{array}{l}\text { Robust sta } \\
*<0.10, \\
\text { ffects of soc } \\
\text { erent in eac } \\
\text { estimated ir } \\
\text { luding mon } \\
\text { Panel F. de } \\
\text { is based on }\end{array}$ & $\begin{array}{l}\text { dard errors in } \\
*<0.05, * * * \\
\text { er tournaments } \\
\text { model. The sa } \\
\text { regressions tha } \\
\text { h fixed effects. } \\
\text { icts placebo re }\end{array}$ & $\begin{array}{l}\text { arentheses ar } \\
0.01 \text {. Data } \\
\text { treat) based } \\
\text { iple consists } \\
\text { control for ye } \\
\text { anel B addi } \\
\text { lts for non-tc }\end{array}$ & $\begin{array}{l}\text { clustered } \\
\text { SOEP } 198 \\
\text { n equation } \\
\text { f unemploy } \\
\text { ar fixed effe } \\
\text { ionally cont }\end{array}$ & $\begin{array}{l}\text { r indviduals. } \\
-2010 \text {. The } \\
\text { The depen- } \\
\text { d individuals. } \\
\text { s and several } \\
\text { ols for demo- } \\
\text { ars where the } \\
\text { he respective }\end{array}$ \\
\hline
\end{tabular}




\subsection{Well-being Variables}

Table 2 displays the effects of soccer tournaments on the set of well-being variables. The table is structured as the previous table with models I - IV showing the effects on different dependent variables (Life Satisfaction, Perceived Health Status, Worries about the Personal Economic Situation, Worries about the General Economic Environment), and Panels $\mathrm{A}-\mathrm{F}$ showing the treatment effects of interest estimated from different regressions.

Panel A, the baseline, depicts that the tournaments have positive effects on perceived health, while life satisfaction is not significantly affected. The effect on the perceived health status is economically relevant as well: being treated increases perceived health by almost one point on the 5-point scale. We further find a negative effect on worries about the general economic situation, but no effect on the perception of the personal economic situation. This is intuitive since people usually have a better understanding of their own finances than of the general economic situation (Dohmen et al., 2006). The results hold if covariates are included in Panel B.

We find negative effects of the tournaments on the subjective well-being of men (Panel A) and mid-aged individuals (D). Additionally, the positive effect on perceived health is the highest among the young and decreasing in age (D). As before the effects are similar to the baseline when East Germany is excluded (E). The placebo tests in Panel $\mathrm{F}$ are again assuring since they yield no significant effects. 
Table 2: Effects on well-being variables

\begin{tabular}{|c|c|c|c|c|}
\hline $\begin{array}{l}\text { Model: } \\
\text { Panel }\end{array}$ & $\begin{array}{c}\text { I } \\
\text { life satisfy }\end{array}$ & $\begin{array}{c}\text { II } \\
\text { health status }\end{array}$ & $\begin{array}{c}\text { III } \\
\text { pers worries }\end{array}$ & $\begin{array}{c}\text { IV } \\
\text { gen worries }\end{array}$ \\
\hline \multicolumn{5}{|l|}{ A. Baseline } \\
\hline$\overline{\text { treat }}$ & $\begin{array}{l}-0.771 \\
(0.696)\end{array}$ & $\begin{array}{c}0.922^{* * *} \\
(0.118)\end{array}$ & $\begin{array}{c}0.063 \\
(0.441)\end{array}$ & $\begin{array}{c}-0.574^{* * *} \\
(0.21)\end{array}$ \\
\hline \multicolumn{5}{|c|}{ B. Including Controls } \\
\hline treat & $\begin{array}{l}-0.651 \\
(0.698)\end{array}$ & $\begin{array}{c}0.705^{* *} \\
(0.32)\end{array}$ & $\begin{array}{c}0.173 \\
(0.453)\end{array}$ & $\begin{array}{c}-0.608^{* * *} \\
(0.225)\end{array}$ \\
\hline \multicolumn{5}{|c|}{ C. Gender Interaction } \\
\hline treat & $\begin{array}{l}-0.995^{*} \\
(0.599)\end{array}$ & $\begin{array}{c}0.847^{* * *} \\
(0.139)\end{array}$ & $\begin{array}{c}0.033 \\
(0.436)\end{array}$ & $\begin{array}{c}-0.568^{* * *} \\
(0.212)\end{array}$ \\
\hline treat $*$ female & $\begin{array}{c}0.457^{* * *} \\
(0.143)\end{array}$ & $\begin{array}{c}0.078 \\
(0.074)\end{array}$ & $\begin{array}{c}0.062 \\
(0.043)\end{array}$ & $\begin{array}{l}-0.012 \\
(0.043)\end{array}$ \\
\hline \multicolumn{5}{|l|}{ D. Age Interaction } \\
\hline treat & $\begin{array}{l}-0.613 \\
(0.793)\end{array}$ & $\begin{array}{c}1.246^{* * *} \\
(0.262)\end{array}$ & $\begin{array}{c}0.097 \\
(0.465)\end{array}$ & $\begin{array}{c}-0.552^{* *} \\
(0.227)\end{array}$ \\
\hline treat $*$ mid-age & $\begin{array}{c}-0.627^{* * *} \\
(0.166)\end{array}$ & $\begin{array}{c}-0.626^{* * *} \\
(0.083)\end{array}$ & $\begin{array}{c}-0.138^{* * *} \\
(0.049)\end{array}$ & $\begin{array}{l}-0.086 \\
(0.053)\end{array}$ \\
\hline treat $*$ old & $\begin{array}{l}-0.057 \\
(0.177)\end{array}$ & $\begin{array}{c}-0.766^{* * *} \\
(0.082)\end{array}$ & $\begin{array}{l}0.106^{*} \\
(0.055)\end{array}$ & $\begin{array}{l}-0.044 \\
(0.051)\end{array}$ \\
\hline \multicolumn{5}{|c|}{ E. West Germany only } \\
\hline treat & $\begin{array}{c}-0.806 \\
(0.713)\end{array}$ & $\begin{array}{c}0.832^{* * *} \\
(0.139)\end{array}$ & $\begin{array}{c}0.017 \\
(0.442)\end{array}$ & $\begin{array}{c}-0.499^{* *} \\
(0.223)\end{array}$ \\
\hline \multicolumn{5}{|l|}{ F. Placebo Test } \\
\hline$\overline{\text { placebo treat }}$ & $\begin{array}{l}-0.315 \\
(0.217) \\
\end{array}$ & $\begin{array}{c}0.049 \\
(0.113) \\
\end{array}$ & $\begin{array}{l}-0.032 \\
(0.059) \\
\end{array}$ & $\begin{array}{l}-0.087 \\
(0.062) \\
\end{array}$ \\
\hline Obs. (baseline) & 12780 & 11918 & 12746 & 12741 \\
\hline Obs. (west only) & 7453 & 6579 & 7425 & 7421 \\
\hline Obs. (placebo) & 11438 & 9688 & 11412 & 11421 \\
\hline $\begin{array}{l}\text { OLS Regressions. } \\
\text { viduals. Significar } \\
1984-2010 \text {. The } \\
\text { on equation 1. Th } \\
\text { consists of unempl } \\
\text { that control for ye } \\
\text { fixed effects. Pane } \\
\text { depicts placebo re } \\
\text { is based on the tou } \\
\text { year. }\end{array}$ & $\begin{array}{l}\text { able display } \\
\text { dependent } \\
\text { yed individy } \\
\text { ar fixed effec } \\
\text { B additiona } \\
\text { ults for non- } \\
\text { nament dat }\end{array}$ & $\begin{array}{l}\text { ard errors in pa } \\
0.10, * *<0 \text {. } \\
\text { the effects of } \mathrm{sc} \\
\text { ariable is differ } \\
\text { ls. All coefficie } \\
\mathrm{s} \text { and several s } \\
\text { ly controls for } \\
\text { ournament yea } \\
\text { of the tournam }\end{array}$ & $\begin{array}{l}\text { entheses are cl } \\
5, * * *<0.0 \\
\text { cer tourname } \\
\text { nt in each mo } \\
\text { ts are estimat } \\
\text { asonal effects } \\
\text { mographic va } \\
\text { where the tr } \\
\text { nt in the respe }\end{array}$ & $\begin{array}{l}\text { tered for indi- } \\
\text { Data: SOEP } \\
\text { (treat) based } \\
\text { The sample } \\
\text { in regressions } \\
\text { luding month } \\
\text { bles. Panel F. } \\
\text { ment dummy } \\
\text { ve subsequent }\end{array}$ \\
\hline
\end{tabular}

\section{Conclusion}

Exploiting the random scheduling of interviewing dates in the SOEP, this paper finds that international soccer tournaments have an impact on different variables which are likely to be relevant for the decision of an unemployed person to start or continue looking for employment. We relate to a strand of literature on the impact of "seemingly irrelevant" (Dohmen et al., 2006) events and provide credible empirical evidence that such factors affect important economic variables.

It is difficult to assess the persistence of our results. ${ }^{10}$ The best we can do is to include an interaction of the treatment variable with a variable measuring the number of

\footnotetext{
${ }^{10}$ Data from a year after a tournament cannot be used to assess this question as all individuals will be "treated" by then.
} 
days between the end of the tournament and the interview. We find that the interaction term is always insignificant and mostly points into the same direction as the treatment effect. We thus conclude that there is no evidence that our results are extremely cursory.

Acknowledgments We would like to thank the editor, an anonymous referee, Denvil Duncan, Markus Gehrsitz, Marco Giesselmann, Daniel S. Hamermesh, Andreas Peichl as well as seminar participants at IZA Bonn for helpful comments and suggestions. The usual disclaimer applies.

\section{References}

Card, D. E., Dahl, G. B., 2011. Family violence and football: The effect of unexpected emotional cues on violent behavior. The Quarterly Journal of Economics 126 (1), 103 143.

Dohmen, T., Falk, A., Huffman, D., Sunde, U., 2006. Seemingly irrelevant events affect economic perceptions and expectations: The FIFA world cup 2006 as a natural experiment, iZA Discussion Paper No 2275.

Edmans, A., Garcia, D., Norli, O., 2007. Sports sentiment and stock returns. The Journal of Finance 62 (4), 1967-1998.

Ehrmann, M., Jansen, D.-J., 2012. The pitch rather than the pit. Investor inattention during FIFA world cup matches, eCB Working Paper Series No 1424.

FIFA, 2010. Bericht ueber TV-Zuschauerzahlen bei der FIFA Fussball- Weltmeisterschaft Suedafrika 2010, online: http://de.fifa.com/mm/document/affederation/tv/01/ 47/31/11/additionalkeyresults_11-00792_101_en_de.pdf.

Gantz, W., Bradley, S. D., Wang, Z., 2006. Televised NFL games, the family, and domestic violence. In: Raney, A. A., Bryant, J. (Eds.), Handbook of Sports and Media. Erlbaum, Mahwah, NJ, pp. 365-382.

Kaplanski, G., Levy, H., 2010. Exploitable predictable irrationality: The FIFA world cup effect on the U.S. stock market. Journal of Financial and Quantitative Analysis 45 (2), $535-553$.

Kavetsos, G., Szymanski, S., 2010. National well-being and international sports events. Journal of Economic Psychology 31 (2), 158 - 171.

Lindo, J. M., Swensen, I. D., Waddell, G. R., 2012. Are big-time sports a threat to student achievement? American Economic Journal: Applied Economics 4 (4), 254-274. 
Lozano, F. A., 2011. The flexibility of the workweek in the United States: Evidence from the FIFA World Cup. Economic Inquiry 49 (2), 512-529.

Rees, D. I., Schnepel, K. T., 2009. College football games and crime. Journal of Sports Economics 10 (1), 68-86.

Scholtens, B., Peenstra, W., 2009. Scoring on the stock exchange? The effect of football matches on stock market returns: an event study. Applied Economics 41 (25), 32313237.

Schüller, S., 2012. The effects of 9/11 on attitudes toward immigration and the moderating role of education, iZA Discussion Paper No. 7052.

SOEP, 2011. Socio Economic Panel, Data for years 1984-2010, Version 27, doi:10.5684/soep.v27.

Thoursie, P. S., 2004. Reporting sick: are sporting events contagious? Journal of Applied Econometrics 19 (6), 809-823. 


\section{Appendices}

\section{A Summary Statistics}

Table A.1: Summary Statistics. Unemployed Individuals

\begin{tabular}{lcccccc}
\hline \hline Variable & \multicolumn{3}{c}{ Treated $(\mathrm{N}=914)$} & \multicolumn{3}{c}{ Control $(\mathrm{N}=11902)$} \\
& mean & $\mathrm{sd}$ & $\mathrm{N}$ & mean & $\mathrm{sd}$ & $\mathrm{N}$ \\
\hline intention & 3.11 & 1.44 & 798 & 3.14 & 1.46 & 10528 \\
diffic find job & 1.74 & 0.57 & 691 & 1.71 & 0.55 & 9613 \\
reservation & 7.09 & 0.43 & 401 & 7.05 & 0.40 & 5209 \\
hours & 3.38 & 0.43 & 89 & 3.38 & 0.51 & 1050 \\
work full-time & 0.78 & 0.41 & 653 & 0.84 & 0.37 & 8581 \\
life satisfy & 5.94 & 2.11 & 909 & 5.73 & 2.09 & 11871 \\
health status & 3.24 & 1.04 & 830 & 3.27 & 1.00 & 11088 \\
pers worries & 1.54 & 0.65 & 908 & 1.53 & 0.63 & 11838 \\
gen worries & 1.73 & 0.65 & 905 & 1.60 & 0.62 & 11836 \\
female & 0.51 & 0.50 & 914 & 0.52 & 0.50 & 11902 \\
age & 40.65 & 13.30 & 914 & 41.93 & 12.90 & 11902 \\
married & 0.46 & 0.50 & 914 & 0.54 & 0.50 & 11902 \\
separated & 0.05 & 0.21 & 914 & 0.03 & 0.17 & 11902 \\
single & 0.31 & 0.46 & 914 & 0.28 & 0.45 & 11902 \\
divorced & 0.15 & 0.36 & 914 & 0.13 & 0.33 & 11902 \\
widowed & 0.02 & 0.14 & 914 & 0.02 & 0.15 & 11902 \\
medium skilled & 0.61 & 0.49 & 914 & 0.66 & 0.47 & 11902 \\
low skilled & 0.24 & 0.42 & 914 & 0.20 & 0.40 & 11902 \\
local unemp. rate & 10.72 & 4.09 & 914 & 14.20 & 5.25 & 11902 \\
\hline \hline
\end{tabular}




\section{B Variables Description}

\begin{tabular}{|c|c|c|c|}
\hline Variable & $\begin{array}{l}\text { SOEP } \\
2010\end{array}$ & Survey Question & Coding \\
\hline Intention & $\begin{array}{l}\text { bap10 \& } \\
\text { bap11 }\end{array}$ & When do you intend to work again? & $\begin{array}{l}0: \text { never, } 1 \text { : in more than } 5 \text { years, } \\
\text { 2: in } 2-5 \text { years, } 3 \text { : within the next } \\
\text { year, } 4 \text { : as soon as possible }\end{array}$ \\
\hline Type of work & bap12 & What type of job are you interested in? & $\begin{array}{l}\text { 1: full-time, } 0 \text { : part-time or indif- } \\
\text { ferent }\end{array}$ \\
\hline Difficulty & bap13 & $\begin{array}{l}\text { If you were looking for a job now: How easy } \\
\text { would it be for you to find a job? }\end{array}$ & $\begin{array}{l}\text { 1: virtually impossible. } 2 \text { : diffi- } \\
\text { cult, } 3 \text { : easy }\end{array}$ \\
\hline Reservation & bap15 & $\begin{array}{l}\text { How high would your monthly net income } \\
\text { be so that you would accept a job offer? }\end{array}$ & in EUR, deflated, logged \\
\hline Desired hours & bap56 & $\begin{array}{l}\text { If you were free to choose your number of } \\
\text { working hours, taking into account poten- } \\
\text { tial changes in income: How many hours } \\
\text { per week would you like to work? }\end{array}$ & logged \\
\hline $\begin{array}{l}\text { Perceived } \\
\text { health }\end{array}$ & bap87 & $\begin{array}{l}\text { How would you describe your current } \\
\text { health condition? }\end{array}$ & $\begin{array}{l}\text { 1: bad, } 2 \text { : not very good, } 3 \text { : satis- } \\
\text { fying, } 4 \text { : good, } 5 \text { : very good }\end{array}$ \\
\hline Well-being & bap160 & $\begin{array}{l}\text { We would like to ask for your general sat- } \\
\text { isfaction with life }\end{array}$ & 0: Low to 10: High \\
\hline $\begin{array}{l}\text { Personal wor- } \\
\text { ries }\end{array}$ & bap13001 & $\begin{array}{l}\text { How about the following issues - are you } \\
\text { worried about: your personal economic sit- } \\
\text { uation }\end{array}$ & $\begin{array}{l}\text { 1: big worries, } 2 \text { : some worries, } 3 \text { : } \\
\text { no worries }\end{array}$ \\
\hline $\begin{array}{l}\text { Economic wor- } \\
\text { ries }\end{array}$ & bap13002 & $\begin{array}{l}\text { How about the following issues - are you } \\
\text { worried about: the general economic situa- } \\
\text { tion }\end{array}$ & $\begin{array}{l}\text { 1: big worries, } 2 \text { : some worries, } 3 \text { : } \\
\text { no worries }\end{array}$ \\
\hline
\end{tabular}




\section{Detailed Regression Results Baseline}

Table C.1: Effects on motivational variables: baseline

\begin{tabular}{|c|c|c|c|c|c|}
\hline $\begin{array}{l}\text { Model } \\
\text { Dependent variable }\end{array}$ & $\begin{array}{c}\text { I } \\
\text { intention }\end{array}$ & $\begin{array}{c}\text { II } \\
\text { diffic find job }\end{array}$ & $\begin{array}{c}\text { III } \\
\text { reservation }\end{array}$ & $\begin{array}{c}\text { IV } \\
\text { hours }\end{array}$ & $\begin{array}{c}\mathrm{V} \\
\text { work full-time }\end{array}$ \\
\hline treatment & $\begin{array}{c}0.819^{* * *} \\
(0.157)\end{array}$ & $\begin{array}{l}0.149^{* *} \\
(0.071)\end{array}$ & $\begin{array}{c}0.508^{* * *} \\
(0.067)\end{array}$ & $\begin{array}{c}0.147 \\
(0.200)\end{array}$ & $\begin{array}{c}0.249^{* * *} \\
(0.052)\end{array}$ \\
\hline local unemp. rate & $\begin{array}{c}0.032^{* * *} \\
(0.004)\end{array}$ & $\begin{array}{c}-0.006^{* * *} \\
(0.001)\end{array}$ & $\begin{array}{c}-0.013^{* * *} \\
(0.001)\end{array}$ & $\begin{array}{c}0.017^{* * *} \\
(0.004)\end{array}$ & $\begin{array}{c}0.010^{* * *} \\
(0.001)\end{array}$ \\
\hline holiday & $\begin{array}{l}3.031^{*} \\
(1.645)\end{array}$ & $\begin{array}{c}0.256 \\
(0.766)\end{array}$ & $\begin{array}{l}-1.133 \\
(0.751)\end{array}$ & $\begin{array}{l}-1.926 \\
(1.248)\end{array}$ & $\begin{array}{l}-0.488 \\
(0.574)\end{array}$ \\
\hline days until holid. & $\begin{array}{c}0.001 \\
(0.001)\end{array}$ & $\begin{array}{l}0.001^{*} \\
(0.000)\end{array}$ & $\begin{array}{l}-0.000 \\
(0.000)\end{array}$ & $\begin{array}{c}0.001 \\
(0.001)\end{array}$ & $\begin{array}{c}0.000 \\
(0.000)\end{array}$ \\
\hline days after holid. & $\begin{array}{l}-0.009 \\
(0.006)\end{array}$ & $\begin{array}{l}-0.000 \\
(0.002)\end{array}$ & $\begin{array}{l}-0.003 \\
(0.002)\end{array}$ & $\begin{array}{c}0.003 \\
(0.004)\end{array}$ & $\begin{array}{c}0.001 \\
(0.002)\end{array}$ \\
\hline used holid. & $\begin{array}{c}-0.078^{* *} \\
(0.039)\end{array}$ & $\begin{array}{l}-0.008 \\
(0.018)\end{array}$ & $\begin{array}{c}0.023 \\
(0.017)\end{array}$ & $\begin{array}{l}0.050^{*} \\
(0.030)\end{array}$ & $\begin{array}{c}0.011 \\
(0.013)\end{array}$ \\
\hline remaining holid. & $\begin{array}{l}-0.071^{*} \\
(0.039)\end{array}$ & $\begin{array}{l}-0.002 \\
(0.018)\end{array}$ & $\begin{array}{c}0.025 \\
(0.018)\end{array}$ & $\begin{array}{c}0.045 \\
(0.029)\end{array}$ & $\begin{array}{c}0.012 \\
(0.013)\end{array}$ \\
\hline sunshine & $\begin{array}{l}-0.003 \\
(0.011)\end{array}$ & $\begin{array}{l}-0.001 \\
(0.005)\end{array}$ & $\begin{array}{c}0.005 \\
(0.004)\end{array}$ & $\begin{array}{c}0.019 \\
(0.012)\end{array}$ & $\begin{array}{c}0.001 \\
(0.003)\end{array}$ \\
\hline rain & $\begin{array}{l}-0.005 \\
(0.007)\end{array}$ & $\begin{array}{c}0.000 \\
(0.003)\end{array}$ & $\begin{array}{c}0.004 \\
(0.003)\end{array}$ & $\begin{array}{l}-0.011 \\
(0.011)\end{array}$ & $\begin{array}{c}0.001 \\
(0.002)\end{array}$ \\
\hline temperature & $\begin{array}{l}-0.008^{*} \\
(0.004)\end{array}$ & $\begin{array}{c}-0.003^{* *} \\
(0.002)\end{array}$ & $\begin{array}{l}-0.002 \\
(0.002)\end{array}$ & $\begin{array}{c}0.002 \\
(0.006)\end{array}$ & $\begin{array}{c}0.001 \\
(0.001)\end{array}$ \\
\hline sunshine squared & $\begin{array}{l}-0.000 \\
(0.001)\end{array}$ & $\begin{array}{l}-0.000 \\
(0.000)\end{array}$ & $\begin{array}{l}-0.000 \\
(0.000)\end{array}$ & $\begin{array}{l}-0.002 \\
(0.001)\end{array}$ & $\begin{array}{l}-0.000 \\
(0.000)\end{array}$ \\
\hline rain squared & $\begin{array}{c}0.000 \\
(0.000)\end{array}$ & $\begin{array}{c}0.000 \\
(0.000)\end{array}$ & $\begin{array}{l}-0.000 \\
(0.000)\end{array}$ & $\begin{array}{c}0.000 \\
(0.001)\end{array}$ & $\begin{array}{l}-0.000 \\
(0.000)\end{array}$ \\
\hline temperature squared & $\begin{array}{c}0.000 \\
(0.000)\end{array}$ & $\begin{array}{c}0.000^{* *} \\
(0.000)\end{array}$ & $\begin{array}{l}-0.000 \\
(0.000)\end{array}$ & $\begin{array}{c}0.000 \\
(0.000)\end{array}$ & $\begin{array}{l}-0.000 \\
(0.000)\end{array}$ \\
\hline january & $\begin{array}{l}-0.968 \\
(0.723)\end{array}$ & $\begin{array}{c}0.230 \\
(0.357)\end{array}$ & $\begin{array}{c}0.300 \\
(0.270)\end{array}$ & $\begin{array}{c}0.256 \\
(0.556)\end{array}$ & $\begin{array}{l}-0.001 \\
(0.196)\end{array}$ \\
\hline february & $\begin{array}{l}-0.905 \\
(0.718)\end{array}$ & $\begin{array}{c}0.280 \\
(0.355)\end{array}$ & $\begin{array}{c}0.314 \\
(0.267)\end{array}$ & $\begin{array}{c}0.303 \\
(0.550)\end{array}$ & $\begin{array}{c}0.006 \\
(0.194)\end{array}$ \\
\hline march & $\begin{array}{l}-0.818 \\
(0.713)\end{array}$ & $\begin{array}{c}0.316 \\
(0.354)\end{array}$ & $\begin{array}{c}0.318 \\
(0.265)\end{array}$ & $\begin{array}{c}0.358 \\
(0.542)\end{array}$ & $\begin{array}{c}0.025 \\
(0.193)\end{array}$ \\
\hline april & $\begin{array}{l}-0.647 \\
(0.709)\end{array}$ & $\begin{array}{c}0.343 \\
(0.353)\end{array}$ & $\begin{array}{c}0.316 \\
(0.263)\end{array}$ & $\begin{array}{c}0.455 \\
(0.534)\end{array}$ & $\begin{array}{c}0.020 \\
(0.192)\end{array}$ \\
\hline may & $\begin{array}{l}-0.605 \\
(0.706)\end{array}$ & $\begin{array}{c}0.342 \\
(0.352)\end{array}$ & $\begin{array}{c}0.325 \\
(0.263)\end{array}$ & $\begin{array}{c}0.443 \\
(0.530)\end{array}$ & $\begin{array}{c}0.071 \\
(0.192)\end{array}$ \\
\hline june & $\begin{array}{l}-0.658 \\
(0.686)\end{array}$ & $\begin{array}{c}0.322 \\
(0.347)\end{array}$ & $\begin{array}{c}0.267 \\
(0.257)\end{array}$ & $\begin{array}{c}0.539 \\
(0.497)\end{array}$ & $\begin{array}{c}0.046 \\
(0.186)\end{array}$ \\
\hline july & $\begin{array}{c}-1.359^{* *} \\
(0.673)\end{array}$ & $\begin{array}{c}0.133 \\
(0.342)\end{array}$ & $\begin{array}{l}-0.067 \\
(0.252)\end{array}$ & $\begin{array}{c}0.302 \\
(0.490)\end{array}$ & $\begin{array}{l}-0.174 \\
(0.183)\end{array}$ \\
\hline august & $-1.291^{* *}$ & 0.189 & -0.135 & 0.224 & -0.216 \\
\hline
\end{tabular}




\begin{tabular}{|c|c|c|c|c|c|}
\hline & \multirow[b]{2}{*}{$(0.641)$} & \multirow[b]{2}{*}{$(0.333)$} & \multicolumn{3}{|c|}{ continued from previous page } \\
\hline & & & $(0.243)$ & $(0.468)$ & $(0.174)$ \\
\hline \multirow[t]{2}{*}{ september } & $-1.084^{*}$ & 0.335 & -0.131 & 0.202 & -0.166 \\
\hline & $(0.582)$ & $(0.306)$ & $(0.216)$ & $(0.530)$ & $(0.155)$ \\
\hline \multirow[t]{2}{*}{ october } & $-0.882^{* *}$ & 0.307 & -0.081 & 0.303 & $-0.240^{* *}$ \\
\hline & $(0.430)$ & $(0.255)$ & $(0.157)$ & $(0.268)$ & $(0.105)$ \\
\hline \multirow[t]{2}{*}{ november } & -0.581 & 0.262 & 0.108 & 0.250 & $-0.237^{* *}$ \\
\hline & $(0.411)$ & $(0.274)$ & $(0.182)$ & $(0.208)$ & $(0.112)$ \\
\hline \multirow[t]{2}{*}{1984} & $0.236^{*}$ & & & & 0.066 \\
\hline & $(0.126)$ & & & & $(0.041)$ \\
\hline \multirow[t]{2}{*}{1986} & 0.110 & & & $-0.312^{* *}$ & -0.017 \\
\hline & $(0.129)$ & & & $(0.155)$ & $(0.041)$ \\
\hline \multirow[t]{2}{*}{1990} & -0.238 & & & -0.047 & \\
\hline & $(0.148)$ & & & $(0.091)$ & \\
\hline \multirow[t]{2}{*}{1992} & -0.150 & -0.051 & & $-0.342^{*}$ & 0.006 \\
\hline & $(0.114)$ & $(0.056)$ & & $(0.205)$ & $(0.036)$ \\
\hline \multirow[t]{2}{*}{1994} & -0.087 & -0.032 & $0.137^{* * *}$ & 0.028 & 0.033 \\
\hline & $(0.110)$ & $(0.055)$ & $(0.026)$ & $(0.087)$ & $(0.035)$ \\
\hline \multirow[t]{2}{*}{1996} & $-0.236^{* *}$ & -0.023 & $0.194^{* * *}$ & & $0.072^{* *}$ \\
\hline & $(0.112)$ & $(0.056)$ & $(0.028)$ & & $(0.034)$ \\
\hline \multirow[t]{2}{*}{1998} & $-0.300^{* * *}$ & -0.072 & $0.184^{* * *}$ & $-0.301^{* * *}$ & 0.036 \\
\hline & $(0.114)$ & $(0.056)$ & $(0.026)$ & $(0.112)$ & $(0.035)$ \\
\hline \multirow[t]{2}{*}{2000} & $-0.375^{* * *}$ & -0.068 & $0.138^{* * *}$ & $-0.254^{* *}$ & $0.058^{*}$ \\
\hline & $(0.111)$ & $(0.056)$ & $(0.026)$ & $(0.104)$ & $(0.035)$ \\
\hline \multirow[t]{2}{*}{2002} & -0.029 & -0.037 & $0.191^{* * *}$ & $-0.262^{* *}$ & 0.042 \\
\hline & $(0.108)$ & $(0.055)$ & $(0.027)$ & $(0.101)$ & $(0.034)$ \\
\hline \multirow[t]{2}{*}{2004} & 0.085 & 0.021 & $0.120^{* * *}$ & $-0.157^{*}$ & 0.031 \\
\hline & $(0.108)$ & $(0.055)$ & $(0.027)$ & $(0.092)$ & $(0.034)$ \\
\hline \multirow[t]{2}{*}{2006} & -0.028 & -0.035 & $0.090^{* * *}$ & $-0.203^{* *}$ & 0.004 \\
\hline & $(0.107)$ & $(0.056)$ & $(0.027)$ & $(0.092)$ & $(0.034)$ \\
\hline \multirow[t]{2}{*}{2008} & 0.026 & 0.004 & -0.021 & -0.137 & 0.011 \\
\hline & $(0.109)$ & $(0.056)$ & $(0.029)$ & $(0.087)$ & $(0.035)$ \\
\hline \multirow[t]{2}{*}{2010} & 0.152 & -0.028 & $0.051^{*}$ & $-0.154^{*}$ & 0.023 \\
\hline & $(0.108)$ & $(0.056)$ & $(0.027)$ & $(0.088)$ & $(0.035)$ \\
\hline \multirow[t]{2}{*}{ constant } & $3.476^{* * *}$ & $1.449^{* * *}$ & $6.855^{* * *}$ & $2.835^{* * *}$ & $0.598^{* * *}$ \\
\hline & $(0.714)$ & $(0.356)$ & $(0.261)$ & $(0.521)$ & $(0.195)$ \\
\hline Adjusted $R^{2}$ & 0.020 & 0.008 & 0.044 & 0.024 & 0.023 \\
\hline Observations & 11326 & 10304 & 5610 & 1139 & 9234 \\
\hline
\end{tabular}

OLS Regressions. Robust standard errors in parentheses are clustered for individuals. Significance levels: $*<0.10, * *<0.05, * * *<0.01$. Data: SOEP $1984-2010$. The table displays the effects of soccer tournaments (treatment) based on equation (1). The dependent variable is different in each model. The sample consists of unemployed individuals. Panel A in Table 1 is based on this regression table. 
Table C.2: Effects on well-being variables: baseline

\begin{tabular}{|c|c|c|c|c|}
\hline $\begin{array}{l}\text { Model } \\
\text { Dependent variable }\end{array}$ & $\begin{array}{c}\text { I } \\
\text { life satisfy }\end{array}$ & $\begin{array}{c}\text { II } \\
\text { health status }\end{array}$ & $\begin{array}{c}\text { III } \\
\text { pers worries }\end{array}$ & $\begin{array}{c}\text { IV } \\
\text { gen worries }\end{array}$ \\
\hline treatment & $\begin{array}{l}-0.771 \\
(0.696)\end{array}$ & $\begin{array}{c}0.922^{* * *} \\
(0.118)\end{array}$ & $\begin{array}{c}0.063 \\
(0.441)\end{array}$ & $\begin{array}{c}-0.574^{* * *} \\
(0.210)\end{array}$ \\
\hline local unemp. rate & $\begin{array}{c}-0.046^{* * *} \\
(0.005)\end{array}$ & $\begin{array}{c}0.012^{* * *} \\
(0.003)\end{array}$ & $\begin{array}{c}-0.010^{* * *} \\
(0.002)\end{array}$ & $\begin{array}{c}-0.011^{* * *} \\
(0.001)\end{array}$ \\
\hline holiday & $\begin{array}{c}2.177 \\
(2.487)\end{array}$ & $\begin{array}{c}0.713 \\
(1.319)\end{array}$ & $\begin{array}{c}0.880 \\
(0.758)\end{array}$ & $\begin{array}{l}-0.181 \\
(0.760)\end{array}$ \\
\hline days until holid. & $\begin{array}{l}-0.001 \\
(0.001)\end{array}$ & $\begin{array}{c}0.000 \\
(0.001)\end{array}$ & $\begin{array}{l}-0.000 \\
(0.000)\end{array}$ & $\begin{array}{c}0.000 \\
(0.000)\end{array}$ \\
\hline days after holid. & $\begin{array}{c}0.003 \\
(0.007)\end{array}$ & $\begin{array}{c}0.001 \\
(0.004)\end{array}$ & $\begin{array}{c}0.001 \\
(0.002)\end{array}$ & $\begin{array}{l}-0.000 \\
(0.002)\end{array}$ \\
\hline used holid. & $\begin{array}{l}-0.057 \\
(0.059)\end{array}$ & $\begin{array}{l}-0.021 \\
(0.031)\end{array}$ & $\begin{array}{l}-0.020 \\
(0.018)\end{array}$ & $\begin{array}{c}0.004 \\
(0.018)\end{array}$ \\
\hline remaining holid. & $\begin{array}{l}-0.047 \\
(0.058)\end{array}$ & $\begin{array}{l}-0.018 \\
(0.031)\end{array}$ & $\begin{array}{l}-0.020 \\
(0.018)\end{array}$ & $\begin{array}{c}0.004 \\
(0.017)\end{array}$ \\
\hline sunshine & $\begin{array}{l}-0.002 \\
(0.015)\end{array}$ & $\begin{array}{l}0.013^{*} \\
(0.008)\end{array}$ & $\begin{array}{l}-0.007 \\
(0.005)\end{array}$ & $\begin{array}{l}-0.005 \\
(0.004)\end{array}$ \\
\hline rain & $\begin{array}{c}0.006 \\
(0.011)\end{array}$ & $\begin{array}{c}0.007 \\
(0.005)\end{array}$ & $\begin{array}{c}0.003 \\
(0.003)\end{array}$ & $\begin{array}{l}-0.001 \\
(0.003)\end{array}$ \\
\hline temperature & $\begin{array}{l}0.014^{* *} \\
(0.006)\end{array}$ & $\begin{array}{c}0.002 \\
(0.003)\end{array}$ & $\begin{array}{l}-0.001 \\
(0.002)\end{array}$ & $\begin{array}{l}-0.003^{*} \\
(0.002)\end{array}$ \\
\hline sunshine squared & $\begin{array}{l}-0.001 \\
(0.001)\end{array}$ & $\begin{array}{c}-0.001^{* *} \\
(0.001)\end{array}$ & $\begin{array}{c}0.001 \\
(0.000)\end{array}$ & $\begin{array}{c}0.000 \\
(0.000)\end{array}$ \\
\hline rain squared & $\begin{array}{l}-0.001 \\
(0.001)\end{array}$ & $\begin{array}{l}-0.000 \\
(0.000)\end{array}$ & $\begin{array}{l}-0.000 \\
(0.000)\end{array}$ & $\begin{array}{c}0.000 \\
(0.000)\end{array}$ \\
\hline temperature squared & $\begin{array}{l}-0.000 \\
(0.000)\end{array}$ & $\begin{array}{l}-0.000 \\
(0.000)\end{array}$ & $\begin{array}{c}0.000 \\
(0.000)\end{array}$ & $\begin{array}{c}0.000 \\
(0.000)\end{array}$ \\
\hline january & $\begin{array}{l}-1.225 \\
(1.377)\end{array}$ & $\begin{array}{c}0.151 \\
(0.575)\end{array}$ & $\begin{array}{l}-0.221 \\
(0.600)\end{array}$ & $\begin{array}{c}-0.835^{*} \\
(0.447)\end{array}$ \\
\hline february & $\begin{array}{l}-1.253 \\
(1.371)\end{array}$ & $\begin{array}{c}0.213 \\
(0.571)\end{array}$ & $\begin{array}{l}-0.196 \\
(0.599)\end{array}$ & $\begin{array}{l}-0.842^{*} \\
(0.445)\end{array}$ \\
\hline march & $\begin{array}{l}-1.359 \\
(1.366)\end{array}$ & $\begin{array}{c}0.228 \\
(0.568)\end{array}$ & $\begin{array}{l}-0.206 \\
(0.598)\end{array}$ & $\begin{array}{l}-0.805^{*} \\
(0.444)\end{array}$ \\
\hline april & $\begin{array}{l}-1.390 \\
(1.362)\end{array}$ & $\begin{array}{c}0.219 \\
(0.566)\end{array}$ & $\begin{array}{l}-0.230 \\
(0.597)\end{array}$ & $\begin{array}{l}-0.763^{*} \\
(0.443)\end{array}$ \\
\hline may & $\begin{array}{l}-1.507 \\
(1.357)\end{array}$ & $\begin{array}{c}0.257 \\
(0.565)\end{array}$ & $\begin{array}{l}-0.277 \\
(0.596)\end{array}$ & $\begin{array}{l}-0.786^{*} \\
(0.442)\end{array}$ \\
\hline june & $\begin{array}{l}-1.525 \\
(1.342)\end{array}$ & $\begin{array}{c}0.210 \\
(0.556)\end{array}$ & $\begin{array}{l}-0.159 \\
(0.592)\end{array}$ & $\begin{array}{l}-0.663 \\
(0.438)\end{array}$ \\
\hline july & $\begin{array}{l}-0.827 \\
(1.162)\end{array}$ & $\begin{array}{l}-0.600 \\
(0.555)\end{array}$ & $\begin{array}{l}-0.348 \\
(0.397)\end{array}$ & $\begin{array}{l}-0.170 \\
(0.387)\end{array}$ \\
\hline august & $\begin{array}{l}-0.808 \\
(1.129)\end{array}$ & $\begin{array}{l}-0.557 \\
(0.538)\end{array}$ & $\begin{array}{l}-0.364 \\
(0.388)\end{array}$ & $\begin{array}{l}-0.089 \\
(0.378)\end{array}$ \\
\hline september & $\begin{array}{l}-0.687 \\
(1.074)\end{array}$ & $\begin{array}{l}-0.666 \\
(0.494)\end{array}$ & $\begin{array}{l}-0.280 \\
(0.369)\end{array}$ & $\begin{array}{l}-0.166 \\
(0.358)\end{array}$ \\
\hline
\end{tabular}




\begin{tabular}{|c|c|c|c|c|}
\hline \multirow[b]{2}{*}{ october } & \multirow[b]{2}{*}{-0.919} & \multirow[b]{2}{*}{$-0.858^{* *}$} & \multicolumn{2}{|c|}{ continued from previous page } \\
\hline & & & -0.360 & -0.046 \\
\hline & $(0.930)$ & $(0.415)$ & $(0.326)$ & $(0.324)$ \\
\hline \multirow[t]{2}{*}{ november } & -1.436 & $-0.735^{*}$ & -0.492 & 0.002 \\
\hline & $(0.954)$ & $(0.410)$ & $(0.317)$ & $(0.321)$ \\
\hline \multirow[t]{2}{*}{1984} & $-0.439^{*}$ & & $-0.242^{* * *}$ & $-0.220^{* * *}$ \\
\hline & $(0.250)$ & & $(0.073)$ & $(0.068)$ \\
\hline \multirow[t]{2}{*}{1986} & 0.030 & & -0.088 & -0.061 \\
\hline & $(0.206)$ & & $(0.072)$ & $(0.067)$ \\
\hline \multirow[t]{2}{*}{1988} & -0.228 & & -0.072 & $-0.173^{* * *}$ \\
\hline & $(0.210)$ & & $(0.073)$ & $(0.064)$ \\
\hline \multirow[t]{2}{*}{1992} & $-0.605^{* * *}$ & & $-0.201^{* * *}$ & $-0.147^{* *}$ \\
\hline & $(0.182)$ & & $(0.061)$ & $(0.057)$ \\
\hline \multirow[t]{2}{*}{1994} & $-0.382^{* *}$ & $-0.242^{* * *}$ & $-0.190^{* * *}$ & $-0.240^{* * *}$ \\
\hline & $(0.180)$ & $(0.045)$ & $(0.061)$ & $(0.056)$ \\
\hline \multirow[t]{2}{*}{1996} & -0.188 & $-0.261^{* * *}$ & $-0.166^{* * *}$ & $-0.193^{* * *}$ \\
\hline & $(0.180)$ & $(0.049)$ & $(0.061)$ & $(0.057)$ \\
\hline \multirow[t]{2}{*}{1998} & -0.220 & $-0.334^{* * *}$ & $-0.214^{* * *}$ & $-0.196^{* * *}$ \\
\hline & $(0.181)$ & $(0.047)$ & $(0.062)$ & $(0.057)$ \\
\hline \multirow[t]{2}{*}{2000} & -0.219 & $-0.388^{* * *}$ & $-0.128^{* *}$ & -0.008 \\
\hline & $(0.179)$ & $(0.046)$ & $(0.061)$ & $(0.056)$ \\
\hline \multirow[t]{2}{*}{2002} & -0.272 & $-0.337^{* * *}$ & $-0.204^{* * *}$ & $-0.178^{* * *}$ \\
\hline & $(0.176)$ & $(0.045)$ & $(0.061)$ & $(0.055)$ \\
\hline \multirow[t]{2}{*}{2004} & $-0.601^{* * *}$ & $-0.320^{* * *}$ & $-0.323^{* * *}$ & $-0.338^{* * *}$ \\
\hline & $(0.177)$ & $(0.045)$ & $(0.061)$ & $(0.055)$ \\
\hline \multirow[t]{2}{*}{2006} & $-0.345^{*}$ & $-0.314^{* * *}$ & $-0.344^{* * *}$ & $-0.294^{* * *}$ \\
\hline & $(0.178)$ & $(0.045)$ & $(0.061)$ & $(0.056)$ \\
\hline \multirow[t]{2}{*}{2008} & $-0.444^{* *}$ & $-0.371^{* * *}$ & $-0.264^{* * *}$ & -0.046 \\
\hline & $(0.177)$ & $(0.047)$ & $(0.061)$ & $(0.056)$ \\
\hline \multirow[t]{2}{*}{2010} & $-0.372^{* *}$ & $-0.405^{* * *}$ & $-0.335^{* * *}$ & $-0.180^{* * *}$ \\
\hline & $(0.178)$ & $(0.049)$ & $(0.061)$ & $(0.056)$ \\
\hline \multirow[t]{2}{*}{ constant } & $8.194^{* * *}$ & $3.161^{* * *}$ & $2.137^{* * *}$ & $2.736^{* * *}$ \\
\hline & $(1.366)$ & $(0.561)$ & $(0.598)$ & $(0.444)$ \\
\hline Adjusted $R^{2}$ & 0.018 & 0.012 & 0.023 & 0.042 \\
\hline Observations & 12780 & 11918 & 12746 & 12741 \\
\hline
\end{tabular}

OLS Regressions. Robust standard errors in parentheses are clustered for individuals. Significance levels: $*<0.10, * *<0.05, * * *<0.01$. Data: SOEP $1984-2010$. The table displays the effects of soccer tournaments (treatment) based on equation (1). The dependent variable is different in each model. The sample consists of unemployed individuals. Panel A in Table 2 is based on this regression table. 